\title{
Attractive Factors of Public Private Partnership (PPP) for Road Projects in Ethiopia
}

\author{
Getachew Yilma Debela \\ Getachew Yilma Debela is an M.Phil. Candidate in the Department of Civil Engineering, School of Engineering, \\ University of Birmingham, UK
}

\begin{abstract}
The private sector has long been involved in delivering public sector projects in Ethiopia but its role limited as consultant and contractor for the government. Over recent years, the interest in adopting Public Private Partnership (PPP) has increased internationally. Many research outcomes have presented positive reasons for the governments and the private sector to welcome this form of long term contract arrangement, rather than continue involving in the traditional procurement methods. This paper aims to explore the attractive factors for PPP implementation in the Ethiopian road sector. A questionnaire survey was conducted in Ethiopia and survey respondents were invited to rate their perceptions on the importance of seventeen different attractive factors identified. The results show that the five important attractive factors for pursuing PPP in the Ethiopian road sector were: 'solve the problem of public sector budget restraint', 'facilitate creative and innovative approaches', 'save time in delivering the project', 'improve maintainability' and 'enhance government integrated solution capacity'. The research outputs contribute to the limited knowledge on PPP practices in Ethiopia by providing empirical evidence on the conditions that are attractive to the introduction of PPP in the road sector.
\end{abstract}

Keywords: Ethiopia, Procurement, Public sector, Private sector, Partnerships, Road infrastructure, Attractive factors

DOI: $10.7176 / \mathrm{JESD} / 10-19-07$

Publication date:October $31^{\text {st }} 2019$

\section{Introduction}

The current Ethiopian government made the road sector one of its priority areas and implemented four Road Sector Development Programs (RSDPs) during the period 1997-2015. The fifth RSDPs are under implementation until 2020. The total budget expended from the public treasury for the road sector in the last nineteen years is estimated to be ETB 266.2 billion (USD 17.4 billion) (ERA, 2016). However, many of the projects planned under the RSDPs were not being completed within the prescribed time and budget and did not meet the quality standards. Consequently, the gap between plan and implementation is hindering the efforts for economic development of the country and together with the growing demand for better road infrastructure (Demissie, 2006). The funding gap in infrastructure is not only due to lack of revenue, but also a consequence of inefficiencies in public spending resulting from poor governance, poor investment planning, and under-investment in maintenance and high operating costs (UNDP, 2015).

The government has also maintained its role in financing the road sector through the conventional methods of procurement. Private sector participation in financing road infrastructure is evidently absent where the lack of a liberalized regulatory framework and competitive market structure hampered the involvement of potential investors ( Foster \& Morella, 2010). The growing global demand for public infrastructure and services has necessitated numerous governments to leverage the private sector's capital and expertise through PPP procurement method ( Osei-Kyei \& Chan, 2017). PPP is a long term contractual arrangement between the public and the private contractor for the delivery of a certain services whereby the private partner assumes substantial risks equivalent to the payment agreed in the contract (World Bank, 2014).

However, over the past years, most of the developing countries including Ethiopia have failed to attract significant private investments in infrastructure as realized in the developed countries. Research findings also suggest that the unique characteristics of PPP in each country influence its attractiveness in the country (Ismail, 2014).

To utilize the advantages of PPP implementation, the Ethiopian government need to have thorough understanding of the drivers of PPP implementation, and to cognize the applicability of international experience to Ethiopia. Thus the objective of this research was to investigate the attractive factors for adopting PPP for road infrastructure development in Ethiopia.

\section{Background to PPP in Ethiopia}

Concessional arrangement for infrastructure development in Ethiopia dates back to the nineteenth century when Emperor Menelik granted to his Swiss adviser, Alfred IIg, to establish a company to build and operate a railway from Djibouti through Harar and Entoto to the White Nile on March 9, 1894 (Pankhurst, 2017). After passing many challenges from regional colonial powers, design changes and financial constraints, the railway construction 
reached Addis Ababa in 1917. The completion of the railway was an event of considerable socio-economic significance for Ethiopia opening the country to international markets (Zewde, 2002).

Since the development of the railway, concession was operational in Ethiopia inspired by the civil law system until the unilateral military government controlled power in 1974 and ended in 1991. In this period, command economy dominated the country and all concessionaires were nationalized. Ethiopia had also formulated a legal instrument to use the private sector investment through a concession arrangement since 1960, though the practice in infrastructure development has been hindered due to different political and economic reasons (Code, 1960).

Though PPP have been rapidly growing in several countries in Europe, Asia, Latin America and many parts of Africa in recent time, its implementation in Ethiopia has so far been limited (Asubonteng, 2011). However, Corbetti Geothermal plc and the Ethiopian government signed an implementation agreement (IA) and a power purchase agreement (PPA) to develop geothermal power in December 2017. This agreement marked a major step in the development of privately financed power generation in Ethiopia. According to the agreement between the parties, the special purpose vehicle company, Corbetti Geothermal plc, will construct 1,000 MW geothermal power plants with an estimated cost of USD 4Billion. The electric power generated will be sold to the Ethiopian government national grid with an agreed rate (Corbetti, 2017).

Encouraged with recent developments, the Ethiopian government understood the need for mobilizing resources from different sources other than the traditional government financing of infrastructure in order to meet the growing demand for public services. To address this issue, in late August 2017 the government established a PPP framework and PPP Unit within the Ministry of Finance and Economic Cooperation (MoFEC).

\section{Literature Review}

Literature review was used to identify relevant attractive factors of PPP implementation, which were then incorporated into the design of a questionnaire. According to Ismail (2014), previous studies on driving forces for adopting PPPs are of two types. The first type refers to literature that discussed the reasons or motivations for adopting PPP without carrying out specific analysis on the reasons. The second type is research that empirically examined the driving factors for PPP implementation. In this study, literature based on theoretical and empirical studies were used to identify the attractive factors that affect PPP implementation. This information was used to design a questionnaire that was sent to potential road sector respondents to gather primary data in the Ethiopian road sector.

Li et al. (2005) conducted a survey to examine the factors attracting PPP implementation in the UK and they identified 15 attractive factors. These were: solves the problem of public sector budget restraint, enhances government integrated solution capacity, reduces public money tied up in capital investment, caps the final service costs, reduces the total project cost, saves time in delivering the project, reduces public sector administration costs, benefit to local economic development, non-recourse or limited recourse public funding, transfer of risk to the private partner, improves maintainability, facilitates creative and innovative approaches, improves buildability, accelerates project development and technology transfer to local enterprise. Furthermore, Li et al. (2005) concluded that it was essential that at an early stage in preparing a business case for PPPs, a clear understanding of the positive factors surrounding the procurement will provide a more informed basis for decision-making. Governments opt to PPPs for various reasons. Liu and Wilkinson (2011) found that the drivers for PPPs adoption include acceleration of infrastructure provision, better risk allocation, whole of life cost savings, improved quality of services, access additional revenue sources, benefits for local economic and social development, and improved project scrutiny.

Attractive factors of PPPs implementation have been studied by many researchers in different administrative regions. Among these, Chan, et al. ( 2009 ) explored and compared the key drivers for adopting PPP in main land China and the Hong Kong Special Administrative Region through a questionnaire survey and the respondents were invited to rate their perceptions on the importance of fifteen different drivers suggested by Li et al. (2005). The findings indicated that respondents from China rated economy-related drivers higher which were: solve the problem of public sector budget restraint; provide an integrated solution for public infrastructure/services; reduce public money tied up in capital investment; cap the final service costs; reduce the total project cost; save time in delivering the project; reduce public sector administration costs; benefit to local economic development; and nonrecourse or limited recourse to public funding.

However, Hong Kong based respondents tended to rate efficiency-related drivers higher including: facilitate creative and innovative approaches; transfer risk to the private partner; improve buildability; improve maintainability; technology transfer to local enterprise; and accelerate project development. Hence, this finding implies that the unique characteristics of PPPs in each country influence the PPP attractiveness in the country (Ismail, 2014). In a related study, Cheung et al. (2009) conducted a questionnaire survey to investigate the reasons for implementing PPPs in three countries namely, Hong Kong, Australia and the UK. The study discovered similarities and differences in the reasons for PPP implementation between the countries. The top three reasons for implementing PPPs in Hong Kong were private initiative, economic development pressure demanding more 
facilities and high quality of services required. In Australia, the three key reasons were high quality of services required, economic development pressure demanding more facilities and inefficiency because of public monopoly and lack of competition. Whereas, the main motivations for implementing PPP in the UK were shortage of government funding, economic development pressure demanding more facilities and avoid public investment restriction.

As countries show economic progress, infrastructure demand to accelerate the economic growth becomes significant. In this regard, governments opt to stretch their capacity to facilitate the required infrastructure from the public budget until deficiency of resources hold them back. In his study through a questionnaire survey of 122 respondents in Malaysia, Ismail (2014), confirmed three top driving forces for PPPs implementation in Malaysia. These were economic development pressure of demanding more facilities, private incentive, and shortage of government funding.

In order to identify the attractive factors of PPPs implementation in the developing countries, Osei-Kyei and Chan (2017) conducted a questionnaire survey with international PPP experts from the academic and industrial sectors. The result indicated that the three most critical factors that attract PPP investment were political support and acceptability for PPPs, government positive attitude towards private sector investments and political stability.

One of the driving forces tempt governments around the world to adopt PPPs implementation is the involvement of the private sector expertise to project development to deliver innovate services than the public sector using the traditional procurement method. In this respect, Almarri (2017) attempted to draw the attractive factors through a questionnaire survey of selected participants from the UAE and the UK. The respondents ranked highest four factors, and these were private sector's skills and experience, private sector's funds, value for money, and risk transfer to the private party.

Government agencies usually prefer to pursue PPPs implementation considering different pressing strategic, political, technical, and economic motivations. Joha and Janssen (2010) examined the motivations of Birmingham City Council to implement PPPs and the authors claimed that the main factors for adopting PPPs were strategic and organizational, political, technical and economic aspects.

Maintenance and handling of infrastructure in developing countries is one of the challenges that affect the provision of proper services to citizens. In their study Ngoma et al. (2014), using a questionnaire survey identified the benefits in the implementation of PPPs construction projects in Zambia. The study established that a reduction in the risk of handling, improvement in the levels of services, provision of economic benefits, savings in construction related costs and increase in infrastructure provision were the most significant benefits of implementing PPPs. In a similar study, Robert et al. (2014), identified five major reasons for the adoption of PPPs for construction projects in Ghana which were: reduces public sector administration cost, allows for shared risk, reduces the problem of public sector budget constraint, private sector possess better mobility and private sector has ability to raise funds for project.

Identification of attractive factors of PPPs implementation can also be used for decision support of government agencies. Cheung and Chan (2011), through a case study by comparing the attractive and negative factors of implementing the Hong Kong Zhuhai Macau Bridge through PPPs, the authors showed that negative factors outweighed attractive factors of the project. Therefore, the use of PPPs to deliver that project could not be justified and the decision of the government coincided with the research outcome.

Based on the foregoing discussion of empirically examined papers, the positive features that influence the attractiveness of PPP in the delivery of public infrastructures are summarized in Table 1. 
Table 1: Summary of Attractive Factors for Adopting PPP Projects

\begin{tabular}{|c|c|c|}
\hline No. & Attractive Factors & Source \\
\hline 1 & $\begin{array}{l}\text { Solve the problem of public } \\
\text { sector budget restraint }\end{array}$ & $\begin{array}{l}\text { (Robert, Dansoh, \& Ofori - Kuragu, 2014), ( Li B. , Akintoye, Edwards, } \\
\text { \& Hardcastle, 2005b), ( Cheung, Chan, \& Kajewski, 2009), (Ismail, } \\
\text { 2014) }\end{array}$ \\
\hline 2 & $\begin{array}{l}\text { Enhance government } \\
\text { integrated solution capacity }\end{array}$ & $\begin{array}{l}\text { ( Li B. , Akintoye, Edwards, \& Hardcastle, 2005b), ( Liu \& Wilkinson, } \\
\text { 2011), ( Cheung, Chan, \& Kajewski, 2009), ( Ngoma, Mundia, \& Kaliba, } \\
\text { 2014) }\end{array}$ \\
\hline 3 & $\begin{array}{l}\text { Reduce public money tied } \\
\text { up in capital investment }\end{array}$ & $\begin{array}{l}\text { ( Li B. , Akintoye, Edwards, \& Hardcastle, 2005b), ( Cheung, Chan, \& } \\
\text { Kajewski, 2009) }\end{array}$ \\
\hline 4 & $\begin{array}{l}\text { Facilitate creative and } \\
\text { innovative approaches }\end{array}$ & $\begin{array}{l}\text { ( Li B. , Akintoye, Edwards, \& Hardcastle, 2005b), ( Cheung, Chan, \& } \\
\text { Kajewski, 2009), (Almarri, 2017), ( Joha \& Janssen, 2010) }\end{array}$ \\
\hline 5 & Reduce the total project cost & $\begin{array}{l}\text { ( Li B. , Akintoye, Edwards, \& Hardcastle, 2005b), ( Liu \& Wilkinson, } \\
\text { 2011), ( Cheung, Chan, \& Kajewski, 2009), (Almarri, 2017) }\end{array}$ \\
\hline 6 & $\begin{array}{l}\text { Save time in delivering the } \\
\text { project }\end{array}$ & $\begin{array}{l}\text { ( Li B. , Akintoye, Edwards, \& Hardcastle, 2005b), ( Cheung, Chan, \& } \\
\text { Kajewski, 2009) }\end{array}$ \\
\hline 7 & $\begin{array}{l}\text { Transfer risk to the private } \\
\text { sector }\end{array}$ & $\begin{array}{l}\text { (Robert, Dansoh, \& Ofori - Kuragu, 2014), ( Liu \& Wilkinson, 2011), } \\
\text { ( Cheung, Chan, \& Kajewski, 2009), (Ismail, 2014), (Almarri, 2017) }\end{array}$ \\
\hline 8 & $\begin{array}{l}\text { Reduce public sector } \\
\text { administration costs }\end{array}$ & $\begin{array}{l}\text { (Robert, Dansoh, \& Ofori - Kuragu, 2014), ( Cheung, Chan, \& } \\
\text { Kajewski, 2009) }\end{array}$ \\
\hline 9 & $\begin{array}{l}\text { Benefit local economic } \\
\text { development }\end{array}$ & $\begin{array}{l}\text { ( Li B. , Akintoye, Edwards, \& Hardcastle, 2005b), ( Liu \& Wilkinson, } \\
\text { 2011), ( Cheung, Chan, \& Kajewski, 2009), ( Ngoma, Mundia, \& Kaliba, } \\
\text { 2014) }\end{array}$ \\
\hline 10 & Improve buildability & $\begin{array}{l}\text { ( Li B. , Akintoye, Edwards, \& Hardcastle, 2005b), ( Cheung, Chan, \& } \\
\text { Kajewski, 2009) }\end{array}$ \\
\hline 11 & Improve maintainability & $\begin{array}{l}\text { ( Li B. , Akintoye, Edwards, \& Hardcastle, 2005b), ( Joha \& Janssen, } \\
\text { 2010), ( Ngoma, Mundia, \& Kaliba, 2014) }\end{array}$ \\
\hline 12 & $\begin{array}{l}\text { Non-recourse or limited } \\
\text { recourse to public funding }\end{array}$ & $\begin{array}{l}\text { ( Li B. , Akintoye, Edwards, \& Hardcastle, 2005b), ( Cheung, Chan, \& } \\
\text { Kajewski, 2009) }\end{array}$ \\
\hline 13 & $\begin{array}{l}\text { Accelerate } \quad \text { project } \\
\text { development }\end{array}$ & $\begin{array}{l}\text { ( Li B., Akintoye, Edwards, \& Hardcastle, 2005b), ( Liu \& Wilkinson, } \\
\text { 2011), ( Cheung, Chan, \& Kajewski, 2009), (Ismail, 2014), ( Ngoma, } \\
\text { Mundia, \& Kaliba, 2014) }\end{array}$ \\
\hline 14 & $\begin{array}{l}\text { Private sector possess better } \\
\text { mobility }\end{array}$ & (Robert, Dansoh, \& Ofori - Kuragu, 2014) \\
\hline 15 & $\begin{array}{l}\text { Private sector has the ability } \\
\text { to raise funds for project }\end{array}$ & $\begin{array}{l}\text { (Robert, Dansoh, \& Ofori - Kuragu, 2014), ( Liu \& Wilkinson, 2011), } \\
\text { (Almarri, 2017) }\end{array}$ \\
\hline 16 & Cap final service costs & $\begin{array}{l}\text { ( Li B. , Akintoye, Edwards, \& Hardcastle, 2005b), ( Cheung, Chan, \& } \\
\text { Kajewski, 2009) }\end{array}$ \\
\hline 17 & $\begin{array}{l}\text { Technology transfer to local } \\
\text { enterprises }\end{array}$ & $\begin{array}{l}\text { ( Li B. , Akintoye, Edwards, \& Hardcastle, 2005b), ( Cheung, Chan, \& } \\
\text { Kajewski, 2009), (Almarri, 2017) }\end{array}$ \\
\hline
\end{tabular}

\section{Methodology}

\subsection{Introduction}

The research started with a systematic literature review to identify the attractive factors of public private partnership (PPP) implementation. By addressing the factors through the literature review, the research investigated the presence of the identified factors in Ethiopia through a structured questionnaire survey. Questionnaire survey is considered to be an effective, convenient, and economical analytical tool for collecting data and sampling the opinions of individuals (Zhang, 2004). Prior to its use, a peer review of the questionnaire was conducted in the University of Birmingham by way of a trial run for checking the wording, identifying ambiguous questions and testing the technique that may be used to collect the data (Naoum, 2013). Finally, the analysis results contributed to the development of conclusion and recommendations for the development of PPP road projects in Ethiopia.

\subsection{Data Collection}

The survey was conducted amongst relevant government organizations, ministries, development partners and private practitioners (contractors and consultants) who were selected based on expert sampling method from the target population of the public, private and development partners working in the Ethiopian road sector. The advantage of this approach is that since experts tend to be more familiar with the subject matter their opinions are more reliable than a sample that includes both experts and non-experts (Bhattacherjee, 2012). 
The respondents were identified based on three main criteria; (i) they must possess adequate knowledge in the area of the Ethiopian government policies and regulations of infrastructure development; (ii) they have involved very closely in the procurement of large infrastructure projects; or (iii) they have served as senior experts or managerial position in their respective area of specialization. The aim was to ensure that the sample for the study was representative of the public sector, private sector and the development partners' perspective. As such, the target experts consisted of respondents drawn from various groups as listed below.

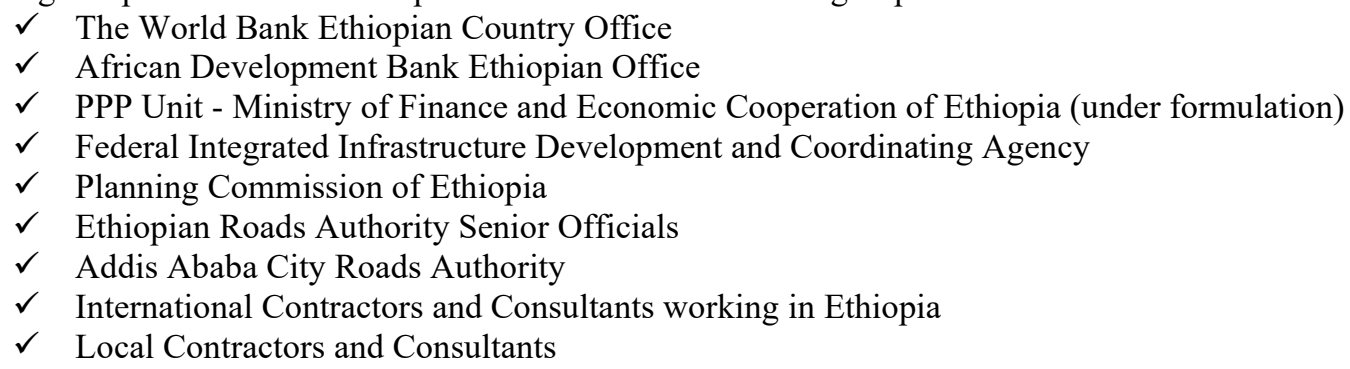

\subsection{Data Analysis Techniques}

Quantitative and qualitative research methods are the two major types of research strategies for data analysis. The research area and the availability of data mainly dictate the type of research method to follow (Naoum, 2013). According to Naoum (2013), quantitative research measures a problem in numbers based on a theory composed of variables objectively. But, qualitative research underlines meanings, experiences and descriptions to subjectively evaluate the opinion, view or perception of respondents towards a particular issue. In this study both qualitative and quantitative research methods were employed for data analysis.

\subsubsection{Qualitative Data Analysis}

Qualitative data analysis of research is concerned with subjective assessment of attitudes, opinions and behaviour (Kothari, 2004). The literature review was analysed by using systematic literature review and content analysis to identify relevant studies to meet the research objectives. Following a qualitative approach, the result of the literature review used to develop the questionnaire to collect the participants' perception on the importance of the attractive factors in the Ethiopian road sector.

\subsubsection{Quantitative Data Analysis}

Quantitative data analysis produces quantified outcomes and conclusions derived from evaluation of results from the literature and collected data (Fellows \& Liu, 2008). The descriptive method of data analysis including the measure of central tendency (mean score) were employed to investigate the distributions of the data given by the respondents (Naoum, 2013). Furthermore, the inferential method of data analysis was also used to measure the relationship between variables.

The data collected was analysed using the Statistical Package for Social Science (SPSS). Therefore, the techniques that were used in this research study, in respect of data analysis include the Mean Score Ranking Technique, $t$ Test, Reliability Test, Relative Agreement Index (RAI) and Kendall's Concordance Analysis as explained below.

\subsubsection{Mean Score Ranking Technique}

The mean score ranking technique has been adopted by many researchers including Ismail (2014), Robert et al. (2014), Cheung and Chan (2011), Cheung, et al. (2012) and Zhang (2005) to establish the relative importance of attractive factors as suggested by group of respondents. In this study, the data collected from the questionnaire survey was also analysed using the same technique.

The mean score (MS) for each factor was computed using equation 1:

$$
\left.M S=\frac{\sum(f x s)}{N} \quad(1<\mathrm{MS}<5) \quad \text { (Eq. }-1\right)
$$

Where $s=$ score set to each factor by the respondents, ranging from 1 to $5 ; \mathrm{f}=$ frequency of each rating for each factor; and, $\mathrm{N}=$ total number of responses concerning that factor. Higher ranking was assigned to the factor/issue with lower standard deviation when two factors score the same mean value (Kavishe et al., 2018).

\subsubsection{One-Sample $t$-test of the Mean Score}

A one sample $t$-test of the mean scores was carried out to measure the significance of the attractive factors in influencing the implementation of PPP road projects in Ethiopia. The rational in conducting the $t$-test was that instead of taking mean values above the average (3.0) as significant (on the 5-point scale), it was proper to show the significance of the factor statistically above the average ( (Ochieng \& Chileshe, 2016), (Ling \& Nguyen, 2013), (Kavishe et al., 2018)). The limit for a 5-point scale was fixed at ' 3.5 ' $(\mathrm{m}=3.5)$ and the analysis for the onesample $t$-test was conducted. With this assumption, the null hypothesis "the identified factors are not significant and less important" was rejected if the mean score was significantly greater than 3.5 at a significance level of less than 0.05. Equation 2 (Nunnally, 1975) was used for the $t$-test: 
Where:

$$
t(d f)=\frac{(M 1-M 2)}{S M D}
$$

$$
\begin{aligned}
& \text { M1 = mean of the group one population } \\
& M 2=\text { mean of the group two population, and } \\
& \text { SMD = the standard error of the difference between the two means. }
\end{aligned}
$$

\subsubsection{Relative Agreement Index (RAI)}

The relative agreement index (RAI) method was used to determine the relative importance of attractive factors as ranked by respondents and the method has been utilized by many researchers ( (Aibinu \& Odeyinka, 2006), (Chileshe \& Kikwasi, 2014), (Kavishe et al., 2018)). The RAI was used to set the level of importance of the factors in the Ethiopian road sector. The RAI was determined using equation 3 (Aibinu \& Odeyinka, 2006).

Where:

$$
\mathrm{RAI}=\frac{\sum \mathrm{W}}{\mathrm{A} \times \mathrm{N}}=(0.2 \leq \mathrm{RAI} \leq 1)
$$

$\mathrm{W}=$ the sum of scoring given to each factor by the respondents (ranging from 1 to 5)

$\mathrm{A}=$ the highest score (i.e. 5 in this case), and

$\mathrm{N}=$ number of respondents assigning the same scoring for the factor/issue

Moreover, the RAI computed was also used to categorize the ranked factors into three grouping of low, medium and high as shown in Table 1.

Table 1 Scoring the Levels of the Importance of Factors

\begin{tabular}{|c|c|c|}
\hline Average Score & RAI & Importance level \\
\hline 4.0 to 5.0 & 0.8 to 1.0 & High (H) \\
\hline 3.0 to $<4.0$ & 0.6 to $<0.8$ & Medium (M) \\
\hline 1.0 to $<3.0$ & 0.2 to $<0.6$ & Low (L) \\
\hline
\end{tabular}

Source: Adapted from (Chileshe \& Kikwasi, 2014)

\subsubsection{Kendall's Coefficient of Concordance}

Kendall's coefficient of concordance, $W$, is an essential non-parametric measure of relationship (Siegel \& Castellan, 1988). It is utilized to determine the degree of agreement among several respondents on a given sets of ranking of factors/issues (Kothari, 2004). Equation 4 (Siegel \& Castellan, 1988) was used to calculate Kendall's coefficient of concordance $(W)$.

$$
\left.W=\frac{\sum(\mathrm{Rj}-\overline{R J})^{2}}{N^{2}(N-1) / 12} \quad \text { (Eq. }-4\right)
$$

Where, $N=$ number of factors ranked;

$R j=$ average of the ranks assigned to the $\mathrm{j}^{\text {th }}$ factor; and

$\overline{R_{j}}=$ average of the ranks assigned across all factors

When the numbers of factors to be ranked are greater than seven, the chi-square is suggested to be employed as a near approximation ( (Siegel \& Castellan, 1988), (Salkind, 2010), (Cha et al., 2010), (Cheung et al., 2012)). The following relationship holds between coefficient of concordance $(\mathrm{W})$ and chi-square with $(\mathrm{N}-1)$ degree of freedom ( (Nunnally, 1975), (Cha et al., 2010)):

$$
\mathrm{X}^{2}=\mathrm{k}(\mathrm{N}-1) \mathrm{W}
$$

Where, $\mathrm{k}=$ number of respondents ranking the factors

$\mathrm{N}=$ number of factors being ranked

The chi-square distribution table can be used to find the critical chi-square value by referring from Siegel and Castellan (1988). When the actual calculated chi-square value equals or surpasses the critical value derived from the table for a certain level of significance, in this case 0.05 , and a certain value of degrees of freedom $(\mathrm{N}-1)$, then the null hypothesis "the set of rankings of factors by respondents was different or unrelated to each other" can be rejected ( (Siegel \& Castellan, 1988), (Cha et al., 2010)).

\subsubsection{Reliability Test}

Cronbach's alpha was used to determine if the multiple Likert scale questions in the questionnaire were reliable. Recent PPP related studies, such as Cheung et al. (2012), have also used similar approaches for reliability analysis. The Cronbach's alpha was computed using equation 6 (Bhattacherjee, 2012):

Where, $\mathrm{K}=$ the number of items,

$$
\alpha=\frac{k \bar{r}}{(1+(k-1) \bar{r})}
$$

$$
\overline{\mathrm{r}}=\text { the average inter-item correlation }
$$

If the computed value of alpha is greater than 0.70 , it indicates a higher level of reliability of the adopted measurement scales (Tavakol \& Dennick, 2011). 


\section{Results and Discussions}

\subsection{Demographic Information}

A total of 85 questionnaires were distributed to selected participants involved in the Ethiopian road sector in various field of assignment from December 2017 to March 2018. Each potential respondent received a cover letter and a copy of the questionnaire. Out of the total target population of 85 experts, the survey was able to collect data from 53 respondents. However, one respondent was excluded from the analysis as it was considered to show insufficient understanding of the questions. Hence, there were a total of 52 usable questionnaires representing a response rate of 61 per cent as shown in Table 3. Considering there are no PPP road projects and there are limited number of potential PPP experts in Ethiopia, 52 responses were considered acceptable for this analysis.

Table 3: Response Rate

\begin{tabular}{|r|c|c|c|}
\hline Type of Survey & $\begin{array}{c}\text { Target number of } \\
\text { respondents }\end{array}$ & $\begin{array}{c}\text { Actual number of } \\
\text { respondents }\end{array}$ & $\begin{array}{c}\text { Response } \\
\text { rate (\%) }\end{array}$ \\
\hline Questionnaire & 85 & 52 & $61 \%$ \\
\hline Total & 85 & 52 & $61 \%$ \\
\hline
\end{tabular}

As illustrated in Table 4, majority of the respondents, 33 (64 per cent), engaged in the private sector including consultants and contractors, 11 (21 per cent) engaged in the public sector, and 8 (15 per cent) are from development partners (the World Bank and the African Development Bank). 14 (27 per cent) of respondents were foreign citizens working in the Ethiopian road sector in various areas of expertise. Majority of the respondents were experts from the private sector comprising contractors and consultants (64 per cent). This result was expected since many professionals are employed in the private sector in the Ethiopian road sector where the research study was concentrated.

Table 4: Distribution of Respondents

\begin{tabular}{|c|c|c|c|}
\hline \multirow{2}{*}{ By Sector } & \multicolumn{2}{|c|}{ Frequency of response } & \multirow{2}{*}{ Percentage $(\%)$} \\
\hline & Target & Actual & \\
\hline Public sector & 20 & 11 & $21 \%$ \\
\hline Private sector & 50 & 33 & $64 \%$ \\
\hline Development partners & 15 & 8 & $15 \%$ \\
\hline Total & 85 & 52 & $100 \%$ \\
\hline
\end{tabular}

Table 5 shows wide spread specialisation of the questionnaire respondents that can enable to collect valuable opinions to answer the research objective. Among the total respondents, the majority of the respondents were road consultants and contractors with $34 \%$ and $22 \%$ respectively. Procurement Specialist and Directors comprised each $10 \%$ of the experts respectively. Though the other experts have experience in other methods of infrastructure procurement, only $6 \%$ of the respondents were PPP experts. This result demonstrates the lack of PPP experts in the Ethiopian road sector.

Table 5: Specialization of Respondents

\begin{tabular}{|l|c|c|}
\hline \multicolumn{1}{|c|}{ Primary Role } & Frequency & Percentage \\
\hline PPP expert & 3 & 6 \\
\hline Procurement Specialist & 5 & 10 \\
\hline Director & 5 & 10 \\
\hline Road Contractor & 12 & 22 \\
\hline Transport Economist & 2 & 4 \\
\hline Financial Advisor & 1 & 2 \\
\hline Road Consultant & 18 & 34 \\
\hline Project Manger & 1 & 2 \\
\hline Transport Engineer & 2 & 4 \\
\hline Macroeconomic Research and Modelling Expert & 1 & 2 \\
\hline Development Plan Implementation Research and Evaluation Expert & 1 & 2 \\
\hline Macro Plan Preparation, Monitoring and Evaluation Team Leader & 1 & 2 \\
\hline
\end{tabular}

\subsection{Ranking of Attractive Factors of PPP Road Projects in Ethiopia}

The target survey respondents of the questionnaire included all industrial practitioners from the public, private and development partners. These respondents were requested to rate their degree of agreement against each of the identified seventeen attractive factors of PPP implementation in the Ethiopian road sector according to a five-point Likert scale $(1=$ Unimportant and $5=$ Most Important). The rankings of the respondents are listed in Table 6 .

The findings presented in Table 4.20 show the attractive factors in descending order ranked by all respondents. The most attractive top five factors were: (1) Solve the problem of public sector budget restraint $($ mean $=4.21, t$ value positive, $p<0.05$ and $\mathrm{RAI}=\mathrm{H})$; (2) Facilitate creative and innovative approaches(mean=4.08, $t$ - value positive, 
$p<0.05$ and $\mathrm{RAI}=\mathrm{H})$; (3) Save time in delivering the $\operatorname{project}($ mean $=4.06, t$ - value positive, $p<0.05$ and $\mathrm{RAI}=\mathrm{H})$; (4) Improve maintainability (mean $=4.04, t$ - value positive, $p<0.05$ and $\mathrm{RAI}=\mathrm{H}$ ) and (5) Enhance government integrated solution capacity (mean $=3.98, t$ - value positive, $p<0.05$ and $\mathrm{RAI}=\mathrm{H}$ ).

Out of the seventeen attractive factors seven of them ranked with mean value ranging from 3.92 to 3.73 with medium relative importance indices namely (6) Improve buildability(mean $=3.92, t$ - value positive, $p<0.05$ and RAI=M), (7) Benefit local economic development(mean=3.81, $t$ - value positive, $p<0.05$ and $\mathrm{RAI}=\mathrm{M})$, (8) Technology transfer to local enterprises(mean=3.79, $t$ - value positive, $p<0.05$ and $\mathrm{RAI}=\mathrm{M})$, (9) Transfer risk to the private sector(mean $=3.77, t$ - value positive, $p<0.05$ and $\mathrm{RAI}=\mathrm{M}),(10)$ Reduce public money tied up in capital investment $($ mean $=3.77, t$ - value positive, $p<0.05$ and $\mathrm{RAI}=\mathrm{M}),(11)$ Accelerate project development $(\mathrm{mean}=3.75$, $t$ - value positive, $p<0.05$ and $\mathrm{RAI}=\mathrm{M})$, and (12) Private sector possess better mobility(mean=3.73, $t$ - value positive, $p<0.05$ and $\mathrm{RAI}=\mathrm{M})$.

Table 6 Attractive Factors of PPP Road Projects in Ethiopia

\begin{tabular}{|c|c|c|c|c|c|c|c|}
\hline Attractive factors & Mean & $\begin{array}{c}t \text {-Test } \\
(\mathrm{m}= \\
3.5)\end{array}$ & $\begin{array}{l}\text { Sig. } \\
\text { (one- } \\
\text { tailed) }\end{array}$ & $\begin{array}{c}\text { Std. } \\
\text { Deviation }\end{array}$ & RAI & Rank & $\begin{array}{c}\text { Level of } \\
\text { Attractiveness }\end{array}$ \\
\hline $\begin{array}{l}\text { Solve the problem of public } \\
\text { sector budget restraint }\end{array}$ & 4.21 & 5.049 & 0.000 & 1.016 & 0.84 & 1 & $\mathbf{H}$ \\
\hline $\begin{array}{l}\text { Facilitate creative and } \\
\text { innovative approaches }\end{array}$ & 4.08 & 5.646 & 0.000 & .737 & 0.82 & 2 & $\mathbf{H}$ \\
\hline $\begin{array}{l}\text { Save time in delivering the } \\
\text { project }\end{array}$ & 4.06 & 5.173 & 0.000 & .777 & 0.81 & 3 & $\mathbf{H}$ \\
\hline Improve maintainability & 4.04 & 6.212 & 0.000 & .625 & 0.81 & 4 & $\mathbf{H}$ \\
\hline $\begin{array}{l}\text { Enhance government } \\
\text { integrated solution capacity }\end{array}$ & 3.98 & 4.186 & 0.000 & .828 & 0.80 & 5 & $\mathbf{H}$ \\
\hline Improve buildability & 3.92 & 4.298 & 0.000 & .710 & 0.78 & 6 & $\mathbf{M}$ \\
\hline $\begin{array}{l}\text { Benefit local economic } \\
\text { development }\end{array}$ & 3.81 & 2.387 & 0.011 & .930 & 0.76 & 7 & $\mathbf{M}$ \\
\hline $\begin{array}{l}\text { Technology transfer to local } \\
\text { enterprises }\end{array}$ & 3.79 & 2.087 & 0.021 & .997 & 0.76 & 8 & $\mathbf{M}$ \\
\hline $\begin{array}{l}\text { Transfer risk to the private } \\
\text { sector }\end{array}$ & 3.77 & 1.976 & 0.027 & .983 & 0.75 & 9 & $\mathbf{M}$ \\
\hline $\begin{array}{l}\text { Reduce public money tied } \\
\text { up in capital investment }\end{array}$ & 3.77 & 2.109 & 0.020 & .921 & 0.75 & 10 & $\mathbf{M}$ \\
\hline $\begin{array}{ll}\begin{array}{l}\text { Accelerate } \\
\text { development }\end{array} & \text { project } \\
\end{array}$ & 3.75 & 2.216 & 0.016 & .813 & 0.75 & 11 & $\mathbf{M}$ \\
\hline $\begin{array}{l}\text { Private sector possess better } \\
\text { mobility }\end{array}$ & 3.73 & 2.320 & 0.012 & .717 & 0.75 & 12 & $\mathbf{M}$ \\
\hline $\begin{array}{l}\text { Reduce public sector } \\
\text { administration costs }\end{array}$ & 3.69 & 1.509 & 0.069 & .919 & 0.74 & 13 & $\mathbf{M}$ \\
\hline $\begin{array}{l}\text { Private sector has the ability } \\
\text { to raise funds for project }\end{array}$ & 3.62 & .960 & 0.171 & .867 & 0.72 & 14 & $\mathbf{M}$ \\
\hline $\begin{array}{l}\text { Non-recourse or limited } \\
\text { recourse to public funding }\end{array}$ & 3.58 & .715 & 0.239 & .776 & 0.72 & 15 & $\mathbf{M}$ \\
\hline Reduce the total project cost & 3.40 & -.647 & 0.260 & 1.071 & 0.68 & 16 & $\mathbf{M}$ \\
\hline Cap final service costs & 3.35 & $\begin{array}{c}- \\
1.698 \\
\end{array}$ & 0.048 & .653 & 0.67 & 17 & $\mathbf{M}$ \\
\hline
\end{tabular}

Note: $\quad$ Results are significant at 95\% level $(P<0.05)$; degree of freedom $(d f)=51$.

Mean score based on total respondents, $N=52$.

RAI = Relative Agreement Index

Four attractive factors were least ranked which were not considered statistically significant $(\mathrm{p}>0.05)$ namely, (13) Reduce public sector administration costs, (14) Private sector has the ability to raise funds for project, (15) Non-recourse or limited recourse to public funding, (16) Reduce the total project cost, and (17) Cap final service costs. Among the least ranked attractive factors two of them scored negative $t$ - value indicating that they are below the test value of 3.5((16) Reduce the total project cost $(t-$ value $=-0.647)$ and (17) Cap final service costs $(t-$ value $=-1.698)$ ).

In the following section, the top five highly ranked attractive factors of PPP implementation in the Ethiopian road sector are discussed in detail.

"Solve the problem of public sector budget restraint" was the most important attractive factor as perceived 
by overall respondents. This finding indicates that PPP type arrangement suits more to those countries where governments have resource constraints and a considerable infrastructure gap exists (Sharma, 2012). Given limited public resources, the formulation of PPP legal framework in Ethiopia provides an opportunity to improve public sector efficiency and private sector development, while attracting foreign resources to support budget constraints (IMF, 2017). Hence, the financing of public sector projects by the private sector has been recognized as one of the key initial driving forces for implementing PPP schemes (Chan et al., 2009).

The second most attractive factor for PPP road projects implementation in Ethiopia as ranked by all respondents was "Facilitate creative and innovative approaches". There has been evidence that by using PPP, the public at large can enjoy better quality services because PPP encourages the private sectors to be innovative and creative in delivering projects (Ismail, 2014). This is a reflection that in the Ethiopian road sector, there is a limitation of capacity in design and project management which is tremendously affecting the public sector budget due to time and cost overrun (CoST, 2016).

The third attractive factor ranked by overall respondents was "Save time in delivering the project". One of the most attractive features of PPP procurement method is that it offers both the public sector and the private contractor more freedom to select innovative methods in the provision of assets and services. This in turn leads to time saving by accelerating project development and by avoiding delays in project delivery (Li et al., 2005b). Public financed project delay in the Ethiopian road sector is a common phenomenon which has been affecting the country's economic prospect in many ways (CoST, 2016).

The fourth ranked attractive factor as rated by all respondents was "Improve maintainability". Under a PPP contract, since the private sector is responsible for design, construction, operation and maintenance, it has the opportunities to consider design suitability and convenience for future maintainability of the project. In the traditional method of procurement, maintenance of road projects is a critical problem in Ethiopia due to quality problem at construction stage and lack of sufficient budget at the assent management stage.

The fifth most attractive factor rated by all respondents was "Enhance government integrated solution capacity". This finding indicates that with PPP procurement, the project scope is capable of expansion to reflect a broader context integrating several components of projects. This might permit the development of an integrated solution, such as binding several activities (design, construction, financing, maintenance, etc.) formerly dealt with under different departments into a single project, thus achieving economies of scale (Li et al., 2005b).

In summary, out of the total seventeen attractive factors ranked by all respondents, the mean score values of four attractive factors were above 4.0 with high level of attractiveness. The mean score values of eleven attractive factors were above 3.5 and less than 4.0 with medium level of attractiveness. These findings revealed that these fifteen factors were perceived to be important attractive factors for the development of PPP road projects in Ethiopia. Only the mean score values of two attractive factors namely; "reduce the total project cost" (mean score $=3.40$ ) and "cap final service costs" (mean score=3.35) were less than 3.5 with medium level of attractiveness.

\subsubsection{Agreement of the Survey Respondents}

The Kendall's coefficient of concordance (W) for the rankings of attractive factors was 0.103 . The computed W was significant with $p=0.000$. As the number of factors considered (17) were above seven, the Chi-square value would be referred to rather than the $\mathrm{W}$ value. According to the degree of freedom, the critical value of Chi-square was 26.296 for the overall respondents and the computed Chi-square value (86.031) was above the critical value of Chi-square (26.296). Therefore, this result indicated that there was a high consensus among the 52 respondents about ranking of which factors are attractive for implementation of PPP road projects in Ethiopia.

\subsubsection{Reliability Test}

Cronbach's alpha coefficient was calculated to verify the internal consistency of the measurement instrument used in the questionnaire. The result of Cronbach's coefficient alpha in this survey was calculated to be 0.838 . Therefore, this finding provides evidence that all the factors have a high internal consistency and reliability.

\section{Conclusion}

The objective of the study was to identify attractive factors of PPP road projects implementation in Ethiopia based on a literature review and the opinion of purposively sampled experts. The mean score analysis conducted determined the relative importance of each factor. The following conclusions are drawn.

- The five most important attractive factors for adopting PPP road projects in Ethiopia in descending order were:

\# Solve the problem of public sector budget restraint;

* Facilitate creative and innovative approaches;

* Save time in delivering the project;

* Improve maintainability; and

* Enhance government integrated solution capacity

- $\quad$ The results of the top attractive factors for PPP road projects adoption in Ethiopia are mainly significant to the government. The government will be beneficiary due to the fact that debt sustainability is a critical 
issue in the Ethiopian financial system as result of excessive commercial borrowing for infrastructure (IMF, 2017).

- In particular, the result showed that an attractive feature of PPP procurement method is that it offers both the public sector and the private sector more freedom to select innovative methods in the provision of assets and services. The presence of factors such as maintainability in the top attractive factors for PPP suggests that this factor may be aligned with innovation in terms of the risk and practicality elements. The opportunity for the private sector to inject its technical expertise much earlier in the project development process is clearly regarded as an attractive feature of PPP by both parties.

- Moreover, PPP is also considered attractive because it is believed to accelerate project development. To ensure fast road project delivery through PPP in Ethiopia, strong coordination between relevant government authorities envisaged to involve in PPP approval need to be organised so that there will be no long delay in any process before the PPP project is awarded to a private company. The achievement of economies of scale, by developing an integrated solution capacity of the government is perceived as an important attractive factor in development of PPP road projects in Ethiopia.

- The attractiveness of the remaining ten factors is also need crucial attention by the public and the private sector as their mean score values were more than 3.5. These ten attractive factors in order of significance were: Improve buildability; Benefit local economic development; Technology transfer to local enterprises; Transfer risk to the private sector; Reduce public money tied up in capital investment; Accelerate project development; Private sector possess better mobility; Reduce public sector administration costs; Private sector has the ability to raise funds for project and; Non-recourse or limited recourse to public funding.

\section{Recommendation}

The under listed recommendations are forwarded to be considered by the government of Ethiopia.

- The government of Ethiopia need to engage the private sector investors through PPP arrangement who have the capabilities of raising substantial funds for road infrastructure development in the country to fill the huge investment gap which cannot be provided by the government alone form the national budget. In this regard, a clear policy and strategy for the private sector participation in financing PPP road projects need to be drafted and communicated to local and international stakeholders through appropriate means.

- In order to ensure that PPP is an attractive and successful procurement tool in the Ethiopian road sector, the government should support innovation by giving more authority to the private sector partner in deciding the design, construction, financing, and operation of PPP road projects when developing the PPP contract.

- It is worth noting that efficiency for PPP road projects come from the capability of the private party in managing the full life cycle of the project under one integrated development system coupled by its technical and financial facilities available for the project.

- In a PPP road project, the private partner is responsible for maintaining the public infrastructure over the concession period. Therefore, it is recommendable to the government of Ethiopia to intensify the process of implementing PPP for new road projects so that the government will be able to focus on the maintenance backlog of already constructed road projects in the country through conventional procurement methods.

\section{Acknowledgements}

This paper forms part of a research project titled "Assessment of Government Policies and Regulation in the Process of Adopting Public Private Partnerships Road Projects in Ethiopia". In the preparation of this study many have contributed invaluable support. Sincere thanks go to the experts at the Ethiopian Roads Authority for their willingness to provide us with all necessary data so that the research work could be carried out. We are also indebted to those industrial practitioners from the public sector, private sector and development partners who kindly participated in the questionnaire survey.

\section{References}

Bhattacherjee, A. (2012). Social Science Research: Principles, Methods, and Practices. Second Edition Copyright (C) 2012 by Anol Bhattacherjee.

Chan, A. P., Lam, P. T., Chan, D. W., Cheung, E., \& Ke, Y. ( 2009 ). Drivers for Adopting Public Private Partnerships-Empirical Comparison between China and Hong Kong Special Administrative Region. JOURNAL OF CONSTRUCTION ENGINEERING AND MANAGEMENT C ASCE / 1115, 1115-1124.

Cheung, E., Chan, A. P., Lam, P. T., Chan, D. W., \& Ke, Y. (2012). A Comparative Study of Critical Success Factors for Public Private Partnerships (PPP) between Mainland China and the Hong Kong Special Administrative Region. Facilities - Special Issue on Facility Management Development (Final Accepted 
Manuscript), Volume 30, Issue 13/14, 647-666.

Cheung, E., Chan, A. P., \& Kajewski, S. (2009). Reasons for implementing public private partnership projects: Perspectives from Hong Kong, Australian and British practitioners. Journal of Property Investment \& Finance Vol. 27 Issue: 1, 81-95.

Fellows, R., \& Liu, A. (2008). Research Methods for Construction Third Edition. John Wiley \& Sons Ltd, The Atrium, Southern Gate, Chichester, West Sussex, PO19 8SQ,Ltd, The Atrium, Southern Gate, Chichester, West Sussex, PO19 8SQ,Ltd, The Atrium, Southern Gate, Chichester, West Sussex, PO19 8SQ,UK.

Foster, V., \& Morella, E. (2010). Ethiopia's Infrastructure:A Continental Perspective. Washington, DC: 2010 The International Bank for Reconstruction and Development / The World Bank.

Joha, A., \& Janssen, M. (2010). Public-private partnerships, outsourcing or shared service centres?: Motives and intents for selecting sourcing configurations. Transforming Government: People, Process and Policy, Vol. 4 Issue: $3,232-248$.

Kavishe, N., Jefferson, I., \& Chileshe, N. (2018). Evaluating issues and outcomes associated with public-private partnership housing project delivery: Tanzanian practitioners' preliminary observations. INTERNATIONAL JOURNAL OF CONSTRUCTION MANAGEMENT DOI:10.1080/15623599.2018.1435154, 1-16.

Li, B., Akintoye, A., Edwards, P., \& Hardcastle, C. (2005b). Perceptions of positive and negative factors influencing the attractiveness of PPP/PFI procurement for construction projects in the UK: Findings from a questionnaire survey. Engineering, Construction and Architectural Management, Vol. 12 Issue: 2, 125-148.

Ling, F. Y., \& Nguyen, D. S. (2013). Construction waste management in India: an exploratory study. Built Environment Project and Asset Management, Vol. 3 (Issue: 1), pp.141-156.

Liu , T., \& Wilkinson, S. (2011). Adopting innovative procurement techniques Obstacles and drivers for adopting public private partnerships in New Zealand. Construction Innovation Vol. 11 No. 4, 452-469.

Ngoma, S., Mundia, M., \& Kaliba, C. (2014). Benefits, Constraints and Risks in Infrastructure Development via Public-Private Partnerships in Zambia. Journal of Construction in Developing Countries, 19(1), 15-33.

Ochieng, J. A., \& Chileshe, N. (2016). Engagement Strategies and Challenges for Adoption of Stakeholder Management Approaches (SMA) In South Australian Construction Industry: Preliminary Observations. Proceedings of the 32nd Conference, 5-7 September 2016 (pp. 921-930). Manchester, UK: Association of Researchers in Construction Management, Vol 2.

Osei-Kyei , R., \& Chan, A. P. (2017). Factors attracting private sector investments in public-private partnerships in developing countries: A survey of international experts. Journal of Financial Management of Property and Construction Vol. 22 Issue: 1, , 92-111.

Sharma, C. (2012). Determinants of PPP in infrastructure in developing economies. Transforming Government: People, Process and Policy, Vol. 6 Iss 2 pp. , 149 - 166.

Tavakol, M., \& Dennick, R. (2011). Making sense of Cronbach's alpha. International Journal of Medical Education. 2011; 2:ISSN: 2042-6372, 53-55.

Zhang, X. (2004). Concessionaire Selection: Methods and Criteria. JOURNAL OF CONSTRUCTION ENGINEERING AND MANAGEMENT 130(2): (C) ASCE / MARCH/APRIL, 235-244.

Aibinu, A. A., \& Odeyinka, H. A. (2006). Construction Delays and Their Causative Factors in Nigeria. JOURNAL OF CONSTRUCTION ENGINEERING AND MANAGEMENT, 132(7), 667-677.

Almarri, K. (2017). Perceptions of the attractive factors for adopting public-private partnerships in the UAE. International Journal of Construction Management, DOI:10.1080/15623599.2017.1382082, 1-9.

Asubonteng, K. A. (2011). THE POTENTIAL FOR PUBLIC PRIVATE PARTNERSHIP (PPP) IN ETHIOPIA. Addis Ababa: Private Sector Development Hub/Addis Ababa Chamber of Commerce and Sectoral Associations Ethiopia.

Cha, D. W., Chan, A. P., \& Choi, T. N. (2010). An empirical survey of the benefits of implementing Pay for Safety Scheme (PFSS) in the Hong Kong construction industry . Journal of Safety Research (JSR), Volume 41( Issue 5), 433-443 .

Chileshe, N., \& Kikwasi, G. J. (2014). Risk assessment and management practices (RAMP) within the Tanzania construction industry: Implementation barriers and advocated solutions. International Journal of Construction Management, Vol. 14(No. 4).

Code, C. (1960). Civil Code of the Empire of Ethiopia Proclamation No.165 of 1960. Addis Ababa: Berhanenna Selam Printing Press.

Corbetti, E. (2017, December 17). www.thinkgeoenergy.com/wp. Retrieved 07 16, 2018, from http://

CoST. (2016). Aggregation, Analysis and Synthesis of Disclosure and Assurance Reports of construction projects covered by CoST-Ethiopia. Addis Ababa,Ethiopia: Construction Sector Transparency Initiative - Ethiopia.

Cronbach, L. J. (1951). COEFFICIENT ALPHA AND THE INTERNALSTRUCTURE OF TESTS. PSYCHOMETRIKA--VOL. 16, NO. 3, 297-333.

Demissie, H. J. (2006). Public Private Partnership in Road Projects in Ethiopia,Public Contracting and Administration of Road Projects and the Ethiopian Roads Authority. Thesis, Berlin. 
ERA. (2016). ROAD SECTOR DEVELOPMENT PROGRAM 19 YEARS PERFORMANCE ASSESSMENT. Addis Ababa: Ethiopian Roads Authority.

Hinton, P. R., Brownlow, C., McMurray, I., \& Cozens, B. (2004). SPSS Explained (Firist edition ed.). London: Routledge.

Holt,, G. D. (2014). Asking questions, analysing answers: relative importance revisited. Construction Innovation, Vol. 14 (Issue: 1), pp.2-16.

IMF. (2017). THE FEDERAL DEMOCRATIC REPUBLIC OF ETHIOPIA. International Monetary Fund,IMF Country Report No. 16/322.

Ismail, S. (2014). Factors Attracting the Use of Public Private Partnership in Malaysia. Journal of Economic and Administrative Sciences Vol. 30 No. 2, 82-95.

Kothari, C. (2004). Research Methodology: Methods and Techniques. New Delhi: NEW AGE INTERNATIONAL (P) LIMITED, PUBLISHERS.

Naoum, S. (2013). Dissertation Research \& Writing for Construction Students Third Edition. Oxford,UK: Butterworth-Heinemann.

Nunnally, J. C. (1975). Introduction to Statistics for Psychology and Education (1 st Edition ed.). New York, US: McGraw-Hill Book Company.

Pankhurst, R. (2017, 4 20). www.everythingharar.com.

Robert, O. K., Dansoh, A., \& Ofori - Kuragu, J. K. (2014). Reasons for adopting Public-Private Partnership (PPP) for construction projects in Ghana. International Journal of Construction Management , 14:4, 227-238, DOI:10.1080/15623599.2014.967925.

Siegel, S., \& Castellan, J. (1988). Nonparametric Statistics for the Behavioral Sciences. 2nd Edition (Second Edition ed.). New York.: McGrawHill.

UNDP. (2015). Prospects of Public- private Partnership (PPP) in Ethiopia. Addis Ababa, Ethiopia: UNDP ETHIOPIA NO. $1 / 2015$.

World Bank. (2014). Public-Private Partnerships Reference Guide Version 2. Washington, D.C.: International Bank for Reconstruction and Development / The World Bank, Asian Development Bank, and Inter-American Development Bank.

Zewde, B. (2002). A history of Modern Ethiopia 1855 - 1991 Second Edition. Addis Ababa: Addis Ababa University Press. 